\title{
CREATION OF A LOW-COST ENDOSCOPIC FLAVECTOMY TRAINING MODEL
}

\author{
CRIAÇÃO DE UM MODELO DE TREINAMENTO EM FLAVECTOMIA ENDOSCÓPICA \\ DE BAIXO CUSTO
}

\section{CREACIÓN DE UN MODELO DE ENTRENAMIENTO EN FLAVECTOMÍA ENDOSCÓPICA DE BAJO COSTO}

\author{
Carolline Popovicz Nunes, ${ }^{1}$ Álynson larocca Kulcheski, ${ }^{2}$ Paula Adamo de Almeida, ${ }^{1}$ Edmar Stieven Filmo, ${ }^{2}$ Xavier Soler Graellis 3 \\ 1. Universidade Federal do Paraná, Curitiba, PR, Brazil. \\ 2. Universidade Federal do Paraná, Department of Surgery, Curitiba, PR, Brazil. \\ 3. Universidade Federal do Paraná, Hospital das Clínicas e Hospital do Trabalhador (HC-HT/UFPR), Curitiba, PR, Brazil.
}

\begin{abstract}
Objective: The objective of the study was the development of a low cost simulator of the endoscopic lumbar spine flavectomy technique for use as a teaching method in order to make endoscopic training more accessible. Methods: The study was a descriptive research project conducted at the Orthopedic Skills Laboratory of the Health Sciences Department of the Federal University of Paraná. Easily accessible, low cost materials, such as a commercial-use mannequin, EVA plastic, PVC and copper tubing were used to develop the simulator.. Results: At the end of the project, it was possible to build a simulator of the endoscopic lumbar spine flavectomy technique with a budget of approximately $464 \mathrm{BRL}$, or approximately $140 \mathrm{USD}$. Conclusions: We concluded that it was possible to build an endoscopic lumbar spine flavectomy technique simulator on a budget of less than half a Brazilian minimum monthly wage, which makes training more accessible to academics, residents and surgeons. Level of Evidence V; Expert opinion.
\end{abstract}

Keywords: Education, Medical; Teaching Methods; Spine; Simulation Training; Endoscopy.

\section{RESUMO}

Objetivo: O objetivo do estudo é o desenvolvimento de um simulador de baixo custo da técnica de flavectomia endoscópica da coluna lombar, para uso como método de ensino, com o propósito de tornar o treinamento endoscópico mais acessível. Métodos: Trata-se de um projeto de pesquisa descritivo, desenvolvido no Laboratório de Habilidades em Ortopedia do Setor de Ciências da Saúde da Universidade Federal do Paraná. Para o desenvolvimento do simulador foram utilizados materiais de fácil acesso e baixo custo, como manequim de uso comercial, plástico EVA, canos de PVC e cobre. Resultados: Ao fim do projeto, foi possível construir o simulador da técnica de flavectomia endoscópica da coluna lombar com orçamento aproximado de 464 reais, aproximadamente 140 dólares. Conclusões: Concluímos que é possível construir um simulador da técnica de flavectomia endoscópica da coluna lombar com orçamento abaixo de meio salário mínimo, o que torna o treinamento mais acessível a acadêmicos, residentes e cirurgiões. Nível de evidência V; Opinião do especialista.

Descritores: Educação Médica; Métodos de Ensino; Coluna Vertebral; Treinamento por Simulação; Endoscopia.

\section{RESUMEN}

Objetivo: El objetivo del estudio es el desarrollo de un simulador de bajo costo de la técnica de flavectomía endoscópica de la columna lumbar para uso como método de enseñanza, con el propósito de hacer que el entrenamiento endoscópico sea más accesible. Métodos: Se trata de un proyecto de investigación descriptivo, desarrollado en el Laboratorio de Habilidades en Ortopedia del Sector de Ciencias de la Universidad Federal de Paraná. Para el desarrollo del simulador fueron usados materiales de fácil acceso y bajo costo, como maniquí de uso comercial, plástico EVA, caños de PVC y cobre. Resultados: Al fin del proyecto, fue posible construir el simulador de la técnica de flavectomía endoscópica de la columna lumbar con presupuesto aproximado de 464 reales, aproximadamente 140 dólares. Conclusiones: Concluimos que es posible construir un simulador de la técnica de flavectomía endoscópica de la coluna lumbar con presupuesto por debajo de medio salario mínimo, lo que hace que el entrenamiento sea más accesible para académicos, residentes y cirujanos. Nivel de evidencia V; Opinión del especialista.

Descriptores: Educación Médica; Métodos de Ensino; Columna Vertebral; Entrenamiento Simulado; Endoscopía.

\section{INTRODUCTION}

Over the last few decades surgical practice has undergone significant changes with the development of minimally invasive surgical techniques. These techniques have become a trend in many surgical fields, including spine surgery. ${ }^{1}$
Kambin and Gellman were the pioneers in the area, looking for a less invasive means of access to lumbar intervertebral disc herniations, introducing the concept of percutaneous endoscopic lumbar discectomy in $1983 .^{2}$ The procedure was then developed and popularized, becoming an important approach for spinal pathologies due 
to the advantages of less tissue trauma, which can improve clinical results and reduce postoperative complications. ${ }^{3}$

Concomitantly with the development of such techniques, teaching and training methods must be elaborated in order to develop the skills used in the videoscopic procedure. ${ }^{4}$ In this way, simulators focused on making the learning process safer and more effective emerged. ${ }^{5}$ Simulation with cadaver specimens is a valuable learning opportunity given the anatomical verisimilitude with real surgery, however, ethical restrictions and availability limit its use. ${ }^{6}$ That said, simulation using synthetic models is an option, offering an opportunity for videoscopic surgical skills development. ${ }^{7}$

Percutaneous endoscopic lumbar discectomy using the interlaminar technique has a steep learning curve due to the high technical demand. ${ }^{8,9}$ The synthetic simulators available on the market for training in this technique are expensive, as they require usually imported high-tech devices, such as monitors, cameras, light sources and optics, limiting access to such training. ${ }^{6}$

In this scenario, the objective of this study is to develop an accessible simulator of the endoscopic lumbar spine flavectomy technique.

\section{METHODS}

\section{Model}

The simulated model is of an adult male lumbosacral spine. A beige plastic commercial-use male mannequin with chest dimensions of $67 \mathrm{~cm}$ in height, $20 \mathrm{~cm}$ in width, and $35 \mathrm{~cm}$ in depth, was used. The mannequin was sawed in half in the coronal direction, following the axial midline. Two hinges were attached at the caudal end. (Figure 1)

Two straight $92 \mathrm{~mm}$ black handles were attached on the left side, one on each half of the mannequin. Two-inch male-female leveling feet were fixed with screws to the proximal and distal portions of the mannequin. In the proximal region, the feet were first attached to a $14 \mathrm{~cm}$ aluminum bar, and then this aluminum bar was fixed to the neck. (Figure 2)

Dots of hot glue were added to the bottom of these feet for anti-slip functionality. To allow access of the endoscopic apparatus, a circular access $25 \mathrm{~mm}$ in diameter was opened in the dorsal region of the mannequin at the level of the L5-S1 transition on the left side. This access was covered with a $2 \times 2 \mathrm{~cm}$ square of beige EVA with a longitudinal opening to simulate the skin with the incision. (Figure 3)

Foam of density 23 and $10 \mathrm{~cm}$ thick was used to fill the internal space of the mannequin. Two $32 \times 13 \times 10 \mathrm{~cm}$ paving stones were used for the ventral half of the mannequin and a $38 \times 31 \times 10 \mathrm{~cm}$ paving stone, cut and shaped to allow the spine to be fit into it, was used to fill the dorsal part. (Figure 4)

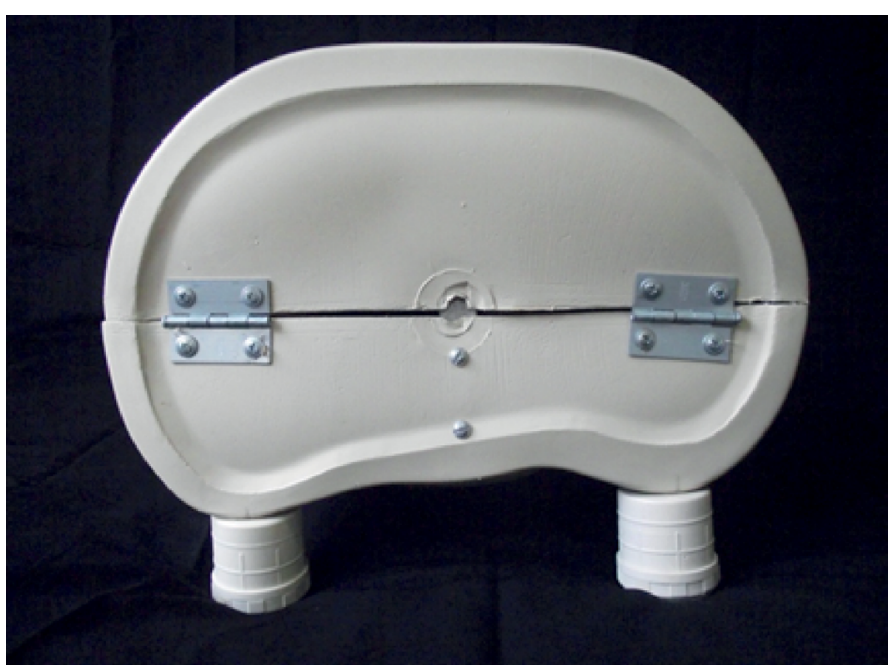

Figure 1. View of the inferior portion of the caudal extremity of the mannequin, with the hinges.

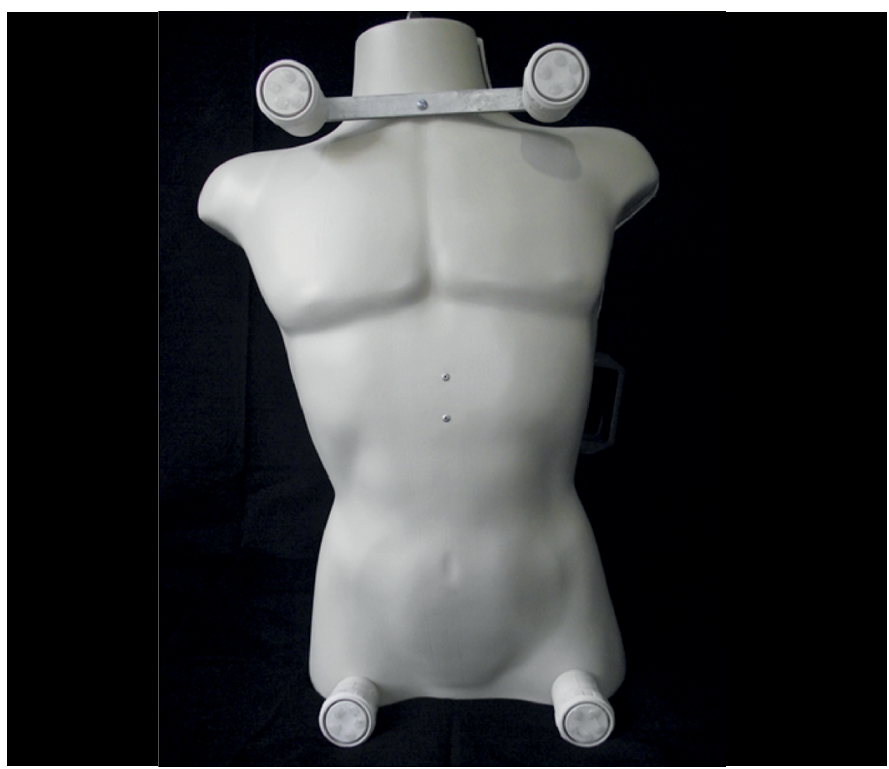

Figure 2. View of the anterior portion of the mannequin, with the four levelling feet attached.

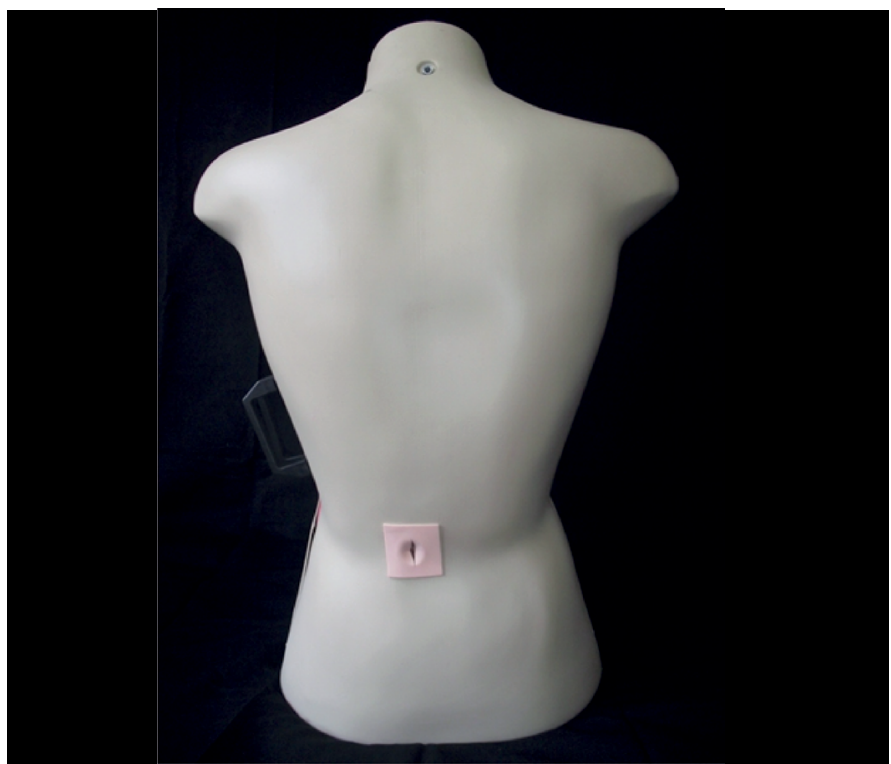

Figure 3. View of the posterior portion of the mannequin, with access at the level of the L5-S1 transition on the left side.

\section{Spine model}

The lumbosacral spine model used, Astral Científica (Astral Cientifica Comercio De Produtos E Equipamentos LTDA, Curitiba, Paraná, Brazil) model EB-3012, is approximately 120x90x330 mm and weighs $775 \mathrm{~g}$. This model is assembled with a metal rod inside, which was retained for fixing the spine to the mannequin. To ensure immobility, the spine was glued to this rod using hot glue. The distal fixation of this rod was accomplished with an aluminum bar, $20 \mathrm{~mm}$ wide and $15 \mathrm{~cm}$ long, which was screwed into the central portion of the mannequin's caudal wall. Proximal fixation was accomplished with a $23 \mathrm{~cm}$ aluminum bracket, with $5 \mathrm{~cm}$ bent into an "L" shape to permit screwing it to the wall of the mannequin and fitting the rod of the spine into the upper part of the bracket. (Figure 5)

\section{Yellow Ligament}

The yellow ligament model was made with yellow EVA paper, cut to $8 \mathrm{~cm}$ wide by $11 \mathrm{~cm}$ long. (Figure 6) To attach the yellow ligament to the spine we had to nail four steel nails to the model spine: two in 


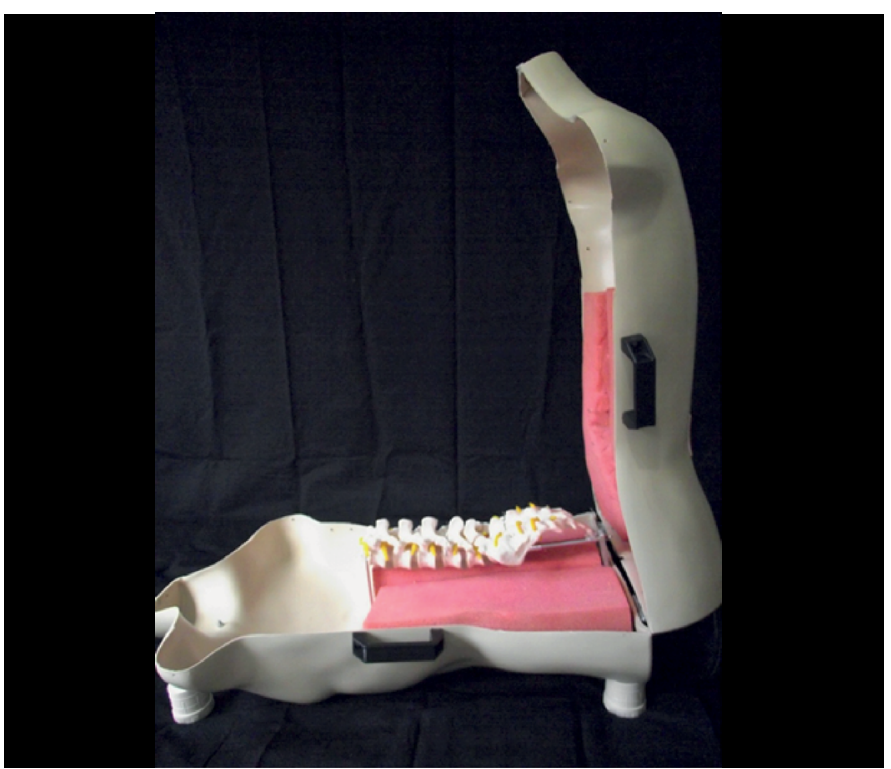

Figure 4. View of the internal space of the mannequin filled with the foam.

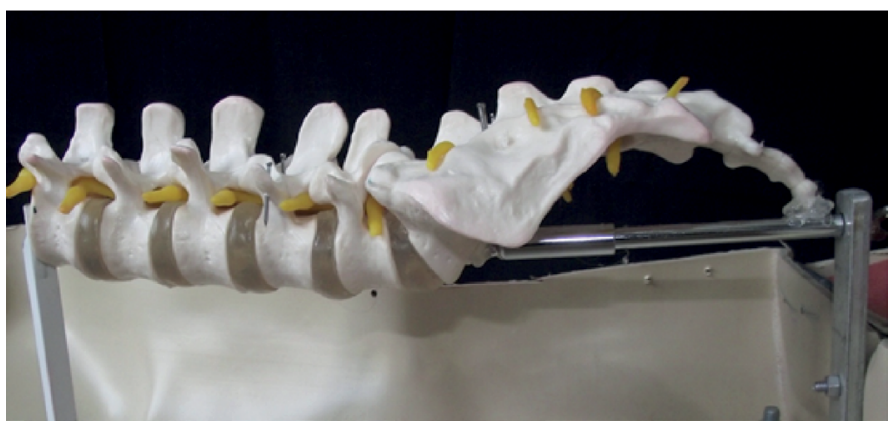

Figure 5. Lateral view of the model of the spine with sacrum, attached to the mannequin.

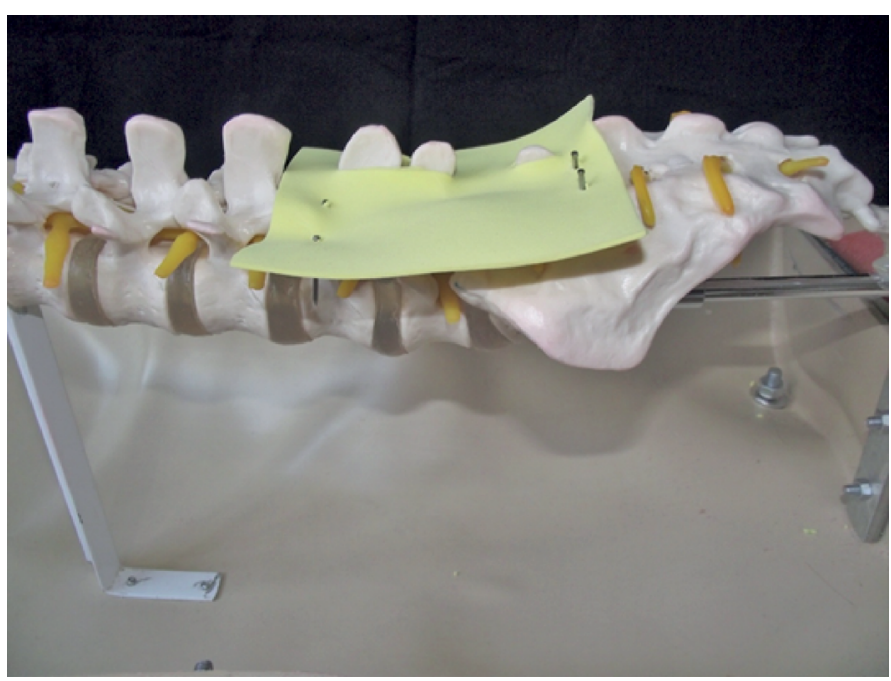

Figure 6. A: Lateral view of the model of the yellow ligament, already attached to the spine; B: Superior view.

the sacrum, one beside the left lateral sacral crest between the first and second posterior sacral foramina; two in the left side of $L 4$, one in the transverse process and the other in the lamina.

\section{Endoscopy}

A PVC tube $15 \mathrm{~mm}$ in diameter by $11 \mathrm{~cm}$ in length was used for the work cannula/sheath, one of the ends of which was cut at a $45^{\circ}$ angle.
A PVC "T" connection was connected to the upper portion of this tube, connected to a $6 \mathrm{~cm}$ tube in its lateral communication. (Figure 7)

A copper tube $10 \mathrm{~mm}$ in diameter and $18 \mathrm{~cm}$ in length with one of its ends cut at a $45^{\circ}$ angle was used for the endoscope. (Figure 7 ) Two plastic straws $5 \mathrm{~mm}$ in diameter and $20.5 \mathrm{~cm}$ in length were placed in the tube using white Polystic silicone. The tube was then fitted to a copper "T" connector $15 \mathrm{~mm}$ in diameter, connected to a $5 \mathrm{~cm}$ tube in its lateral communication. A probe-type inspection camera with LED light and USB port, KKMOON model SXT-5.0M was glued in one of the plastic straws.

These materials have a total cost of approximately $73 \mathrm{BRL}$ (approximately 22 USD).

\section{RESULTS}

The simulator for the endoscopic lumbar spine flavectomy was built using easily accessible materials on a budget of less than half of the Brazilian minimum monthly salary. Table 1 shows the description of the materials and their respective costs. Figure 8 shows the final assembly with the simulator in use, while Figure 9 shows the image obtained by the simulator during the flavectomy.

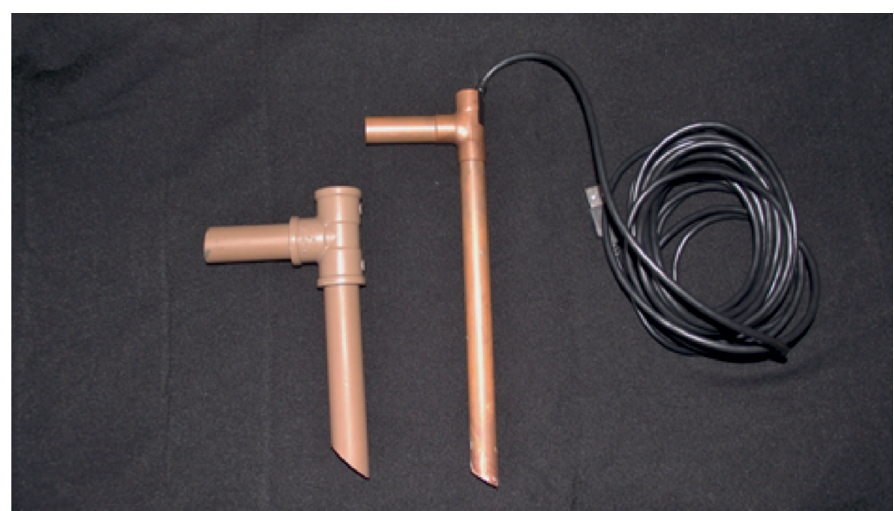

Figure 7. On the right, the work cannula made with PVC tubing, and on the left the endoscope made with copper tubing.

Table 1. Description of the materials and their respective costs.

\begin{tabular}{c|c}
\hline Material & Cost (in BRL) \\
\hline Model & \\
\hline Mannequin & $\mathrm{R} \$ 36.00$ \\
\hline Foam & $\mathrm{R} \$ 30.00$ \\
\hline Leveling feet & $\mathrm{R} \$ 20.00$ \\
\hline Handles and hinges & $\mathrm{R} \$ 5.00$ \\
\hline Aluminum bar & $\mathrm{R} \$ 5.00$ \\
\hline Screws and nuts & $\mathrm{R} \$ 2.50$ \\
\hline Spine model & $\mathrm{R} \$ 288.00$ \\
\hline Spine & $\mathrm{R} \$ 10.00$ \\
\hline Aluminum bar & $\mathrm{R} \$ 5.00$ \\
\hline Aluminum bracket & $\mathrm{R} \$ 2.50$ \\
\hline Screws and nuts & $\mathrm{R} \$ 1.60$ \\
\hline Yellow ligament & $\mathrm{R} \$ 0.50$ \\
\hline EVA & $\mathrm{R} \$ 5.00$ \\
\hline Nails & $\mathrm{R} \$ 6.00$ \\
\hline Endoscope & $\mathrm{R} \$ 5.00$ \\
\hline PVC tube and connection & $\mathrm{R} \$ 0.50$ \\
\hline Copper tube and connection & $\mathrm{R} \$ 42.00$ \\
\hline Silicone sealant & $\mathrm{R} \$ 464.60$ \\
\hline Plastic straw &
\end{tabular}




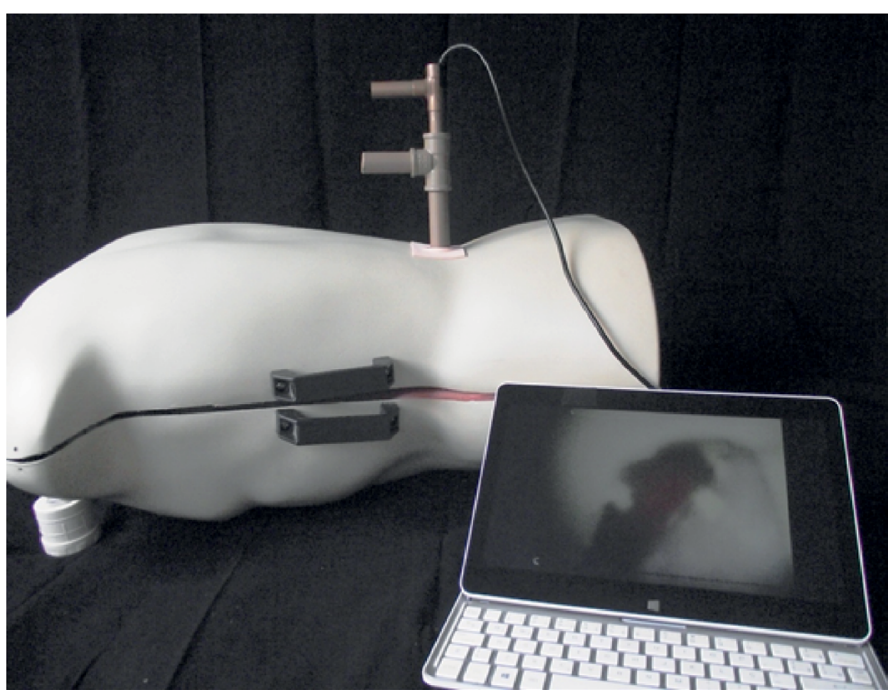

Figure 8. Completed simulator assembly in use.

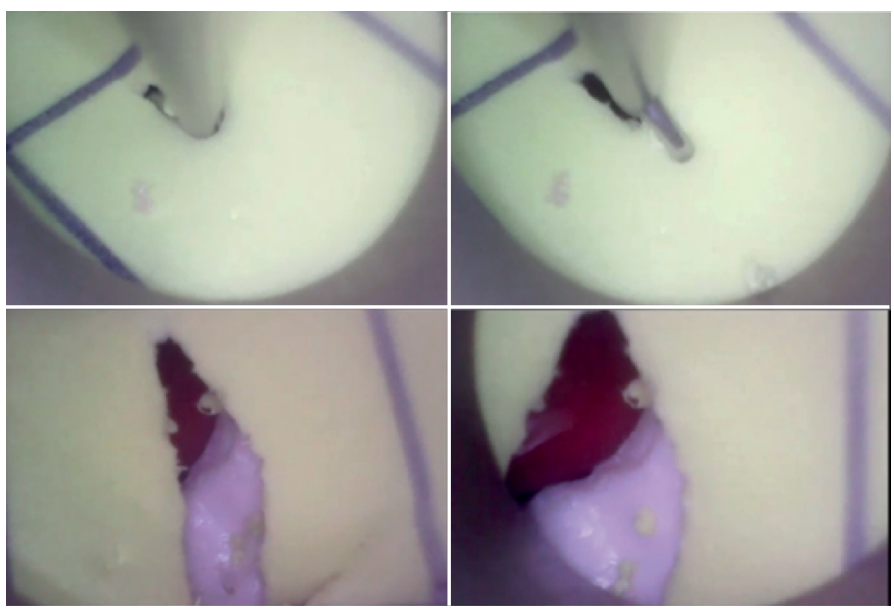

Figure 9. Images obtained by the videoscope during execution of the flavectomy procedure in the simulator

\section{DISCUSSION}

Minimally invasive surgical techniques using videoscopy have become a trend in many areas of medicine, particularly in spine surgery. ${ }^{1}$ Synchronously to the development of such techniques, it was necessary to elaborate teaching and training methods, since they demand psychomotor skills different from those used in open surgeries. ${ }^{4}$ In this context, synthetic simulators appeared as a teaching and training option, however, the models available on the market are expensive, limiting access to this type of learning. ${ }^{10,11}$

The objective of this study was to develop a simulator for the endoscopic spinal flavectomy technique using easily accessible and low-cost materials, making reproducing it possible for any interested professional. By the end of the project, we had succeeded in building the simulator for less than half of the Brazilian minimum monthly salary (a total of approximately 464 BRL, approximately 140 USD), which makes training accessible. This is significant since research has shown that simulation, if performed only once, is not sufficient to ensure adequate learning, but is if progressive training based on repetition is adopted. ${ }^{12} \mathrm{Up}$ to the time this article was published, no similar study seeking to develop a spine surgery simulator with easily accessible materials enabling reproducibility existed in the literature. Only studies about simulators constructed as prototypes using synthetic materials, expensive to produce and not reproducible by other interested people can be found. ${ }^{13}$

Another advantage of the developed simulator is its portability, being easily transportable for training at different locations. Such mobility can encourage and facilitate the learning process just as portable computers have facilitated the teaching process in the most diverse areas of knowledge in recent years. ${ }^{14}$

Simulators enable the development of basic motor, visual, and spatial skills, improving the performance of the surgeon performing a videoscopic procedure on a real patient. ${ }^{8}$ Training becomes essential since the field of observation is limited and the capacity for instrument manipulation is reduced. ${ }^{4}$ During the development of the simulator, we found it difficult to faithfully replicate the field of vision and the manipulation of materials using copper or PVC tubes because they had larger dimensions than real instruments. One solution we found was the introduction of plastic commercial-use straws inside the copper tube to restrict the material handling capacity, similarly to what occurs in the surgical procedure. Up until the publication of this article, we did not find any study that developed a videoscope for the simulation of minimally invasive spine surgery in the literature. However, there are studies about the construction of endoscopes in other areas. For example, one study developed an endoscopic ventriculostomy simulator using a borescope camera with LED light, stainless steel straw, and parts printed by a 3D printer. ${ }^{15}$ While the final result is esthetically more faithful to the real instrument, use of the 3D printer limits the access to and the reproducibility of the simulator.

The yellow ligaments are formed from large, light yellow bands of elastic tissue that join the laminas of the adjacent vertebrae. They are thin in the cervical region and become thicker in the lumbar region. ${ }^{16}$ Replicating them is an important part of the simulator development, since the flavectomy is the focus of the simulation, and studies have proven that the more realistic the simulator, the better the training environment and the better the transfer of skills. ${ }^{17}$ For our simulator, it was essential that the ligament be as similar as possible to the real structure and, at the same time, be made from easily accessible material. For this, we tested several materials, such as satin ribbon, rubber bands, and pieces of EVA. After several tests, including discussions with spine surgery professionals, it was concluded that EVA provided a suitable replication of the real structure with the great advantage of being an easily accessible, low-cost product permitting easy replacement of the ligament in each flavectomy training session. We did not find any studies in the literature that specifically sought specific replication of the ligament. It is possible to find studies on the development of lumbar puncture simulators that address the ligament's resistance to puncture. For example, one study designed an epidural simulator to simulate loss of resistance and the varying degrees of pressure resistance in each type of tissue and found that resistance to the $1 \mathrm{~mL}$ syringe simulated the yellow ligament. ${ }^{18}$ Another study attempted to compare a simulator made with a block of melamine resin foam and a latex rubber sheet with a simulator made from a piece of pork loin and with a commercial simulator, finding similar levels of resistance to needle insertion through the yellow ligament. ${ }^{19}$ Despite these findings, we believed that it would not be feasible to use these materials in the simulator and decided to use EVA

It is difficult to realistically replicate the soft tissues maintaining properties similar to those of the real structures, such as tissue deformity. ${ }^{20}$ During project development we were careful to look for materials that could replicate the anatomical structures, even though the replication is not perfect. An example of this is the choice of a commercially used mannequin, the shape of which is more like the human body, even though the density and malleability of the plastic are different. In addition, we chose to fill the interior of the mannequin with foam to simulate the musculature and subcutaneous tissue, which fulfilled the function of guiding the procedure even though it did not provide a perfect replication of the structures. One study that sought to develop artificial muscles for a minimally invasive spinal surgery simulator found that silicone rubber presented adequate haptic feedback for the simulation. ${ }^{21}$ However, because our objectives were low cost, easy reproducibility of the simulator, and a specific focus on the endoscopic flavectomy procedure, we chose to use foam blocks rather than silicone, as they are more accessible. 
Another limitation we encountered was the impossibility of replicating surgical instruments, such as scissors and grasping forceps, to perform the procedure. To perform a percutaneous endoscopic lumbar discectomy procedure, the instrument must be about 165 $\mathrm{mm}$ by $5.6 \mathrm{~mm}$, the working channel about $4.1 \mathrm{~mm}$, and instruments, such as scissors and forceps, must be about 3-4 mm. ${ }^{22}$ We looked for materials to substitute the instruments used in the procedure, but none were sufficiently similar. To replicate the work cannula/sheath and endoscope we used copper and PVC tubes that, while with dimensions greater than those of the actual tools used in surgery, proved to be effective in performing the simulation of the procedure using the model.

Finally, the use of this simulator as a teaching method still needs to be validated using an efficient and objective evaluation method, such as GOALS (Global Operative Assessment of Laparoscopic Skills), which is used to assess surgical skills.

\section{CONCLUSION}

It is possible to build a simulator for the endoscopic spinal flavectomy technique using easily accessible materials for less than half of the Brazilian minimum monthly salary.

All authors declare no potential conflict of interest related to this article.

CONTRIBUTION OF THE AUTHORS: Each author made significant individual contributions to this manuscript. CPN: elaboration of the project, writing of the article, data analysis. ALK: elaboration of the project, writing and review of the article. PAA: review of the article. ESF: writing, review and intellectual concept of the article. XSG: review of the article.

\section{REFERENCES}

1. $A E$, Veeravagu A, Oyelese AA, Gokaslan + 3ZL. A Brief History of Endoscopic Spine Surgery. Neurosurg Focus. 2016;40(2):E2.

2. Kambin $P$, Gellman H. Percutaneous lateral discectomy of the lumbar spine. A preliminary report. Clin Orthop. 1983;174:127-32.

3. Ruetten S, Komp M, Merk HR, Godolias G. Full-endoscopic interlaminar and transforaminal lumbar discectomy versus conventional microsurgical technique: a prospective, randomized, controlled study. Spine (Phila Pa 1976). 2008;33(9):931-9

4. Pedowitz RA, Esch J, Snyder S. Evaluation of a virtual reality simulator for arthroscopy skills development. Arthroscopy. 2002;18(6):E29.

5. Tashiro Y, Miura H, Nakanishi Y, Okazaki K, Iwamoto Y. Evaluation of skills in arthroscopic training based on trajectory and force data. Clin Orthop Relat Res. 2009:467(2):546-52.

6. Molin FFD, Mothes FC. Feder MG. Eficácia do aprendizado da videoartroscopia em modelos sintéticos. Rev Bras Ortop. 2012;47(1):83-91.

7. Frank RM, Erickson B, Frank JM, Bush-Joseph CA, Bach BR, Cole BJ, et al. Utility of modern arthroscopic simulator training models. Arthroscopy. 2014;30(1):121-33.

8. Unalan PC, Akan K, Orhun H, Akgun U, Poyanli O, Baykan A, et al. A basic arthroscopy course based on motor skill training. Knee Surg Sports Traumatol Arthrosc. 2010;18(10):1395-9.

9. Wang H, Huang B, Li C, Zhang Z, Wang J, Zheng W, et al. Learning curve for percutaneous endoscopic lumbar discectomy depending on the surgeon's training level of minimally invasive spine surgery. Clin Neurol Neurosurg. 2013:115(10):1987-91.

10. Wills DP, Chapman PM. An efficient method for modelling soft tissue in virtual environment training systems. Stud Health Technol Inform. 2001:81:570-6.

11. McCarthy AD, Hollands RJ. A commercially viable virtual reality knee arthroscopy training system. Stud Health Technol Inform. 1998;50:302-8.

12. Arealis G, Holton J, Rodrigues JB, Sagkrioti M, Snow M, Hamlet M, et al. How to Build Your Simple and Cost-effective Arthroscopic Skills Simulator. Arthrosc Tech. 2016;5(5):e1039-47.

13. Adermann J, Geissler N, Bernal LE, Kotzsch S, Korb W. Development and validation of an ar- tificial wetlab training system for the lumbar discectomy. Eur Spine J. 2014;23(9):1978-83 14. de Almeida MEB. Tecnologias na Educação: dos caminhos trilhados aos atuais desafios. BOLEMA. 2008:21(29):99-129.

15. Garling R, Jin X, Yang J, Khasawneh AH, Harris C. Low-cost endoscopic third ventriculostomy simulator with mimetic endoscope. J Neurosurg Pediatr. 2018;22(2):137-46.

16. Moore KL. Anatomia Orientada para a Prática Clínica. 4ed. Rio de Janeiro: Guanabara Koogan; 2001.

17. Lehmann KS, Ritz JP, Maass H, Cakmak HK, Kuehnapfel UG, Germer CT, et al. A prospective randomized study to test the transfer of basic psychomotor skills from virtual reality to physical reality in a comparable training setting. Ann Surg. 2005;241(3):442-9.

18. Jeong SM, Choi JM, Kim JH, Yoo H, Lee S, Seo H, et al. A proposal of a simple epidural simulator for training novice anesthesiologists. J Anesth. 2016;30(4):591-5.

19. Naemura K, Sakai A, Hayashi T, Saito H. Epidural insertion simulator of higher insertion resistance and drop rate after puncture. Conf Proc IEEE Eng Med Biol Soc. 2008;2008:3249-52

20. Stroem P. Hedman L, Saerna L, Kjellin A. Wredmark T, Fellaender-Tsai L. Early exposure to haptic feedback enhances performance in surgical simulator training: a prospective randomized crossover study in surgical residents. Surg Endosc. 2006;20(9):1383-8.

21. Hollensteiner M, Fürst D, Augat $P$, Schrödl F, Esterer B, Gabauer $S$, et al. Characterization of an artificial skull cap for cranio-maxillofacial surgery training. J Mater Sci Mater Med. 2018;29(9):135.

22. VERTEBRIS Lumbar-Thoracic. Full-endoscopic Spinal Instrumentation. Catálogo comercial da empresa Richard Wolf. [Acesso em 13 mar. 2018] Disponível em: http:// www.richard-wolf.com/broschueren/Spine/B_756_VERTEBRIS_lumbal-thorakal IV16 en web.pdf

23. Vassiliou MC, Feldman LS, Andrew CG, Bergman S, Leffondré K, Stanbridge D, et al. A global assessment tool for evaluation of intra operative laparoscopic skills. Am J Surg. 2005;190(1):107-13. 